\title{
Experimental Study of Sand Mold Process Parameters on Al-Alloy Sand Castings Using DoE.
}

\author{
Mohammed Viquar Mohiuddin ${ }^{1}$, Syed Ferhathullah Hussainy ${ }^{2}$ \\ A. Krishnaiah ${ }^{3}$, P. Laxminarayana ${ }^{4}$ and S. Sundarrajan ${ }^{5}$. \\ ${ }^{1,2}$ (M.E.D., Muffakham Jah College of Engineering \& Technology, India) \\ ${ }^{3,4}$ (M.E.D., Osmania University, India) \\ ${ }^{5}$ (M.E.D., National Institute of Technology - Tiruchirappalli, India)
}

\begin{abstract}
Aluminum alloy castings are extensively used in general engineering, automobile, aerospace industries due to their excellent castability, machineability, corrosion resistance and high strength-to-weight ratio. Keeping in view the increase in demand for the use of aluminum in manufacturing of various components, aluminum foundries have to focus on producing quality castings. Sand mould casting process involves parameters like sand grain size, clay content, moisture content, permeability, green compression strength, mold hardness, number of ramming, shatter index, type of mold, etc., just to mention a few. Based on literature survey, brainstorming and experimental constraints; Grain size, Clay content, Moisture content and Number of ramming has been selected as process parameters keeping other parameters constant. Experiments were conducted as per Taguchi's L9 orthogonal array. Castings are made under the constraint of process parameters at three different levels. Results were evaluated to optimize the process parameters. The optimum levels are found to be: Grain size-55, Clay content-12\%, Moisture content-13\%, Number of ramming's-2. Confirmation test is conducted based on the optimum level of process parameters and result is found to be in confidence level.
\end{abstract} Keywords - Aluminium alloys, Design of Experiment (DoE), Sand casting process parameters, Taguchi method.

\section{INTRODUCTION}

Sand molding is a very ancient technique of manufacturing the product and is used to manufacture complex shape castings of various sizes depending upon the requirements. But still despite of science getting to new level every passing minute, there are defects, flaws or imperfections which still remain and are very difficult to eliminate from castings.

In the present competitive environment, it is of paramount importance to maintain the quality of the castings and to aim at products with 'zero-defect' and 'right the first time'. The key element for achieving high quality and low cost product is parameter design. Through parameter design optimal levels of process parameters (or control factors) are selected [1]. These parameters should be controlled to improve the quality of both casting process and the product. Numbers of problems of various types are associated with the casting process. These problems may be related to casting yield, defects, dimensional variations, solidification, surface texture, poor mechanical properties, porosities and so on [2]. If the casting process is not being managed properly, the problems may aggravate further resulting in defects which render the product weak and of low quality, thus making them unfit for use [3]. Therefore to overcome the problems in the casting, optimization of the process parameters should be done. Optimization is required right from the stage of selecting the sand to the removal of casting from the sand mold.

Quality improvement in foundry industry have been carried over by researchers and foundry engineers for robust product at the customers end by applying various optimization methods to the sand casting process parameters: the Gradient search method, the Finite element method (FEM) and the Taguchi method [4]. Taguchi has introduced several statistical tools and concepts of quality improvement that depend heavily on the statistical theory of experimental design. Some applications of Taguchi's method in the foundry industry have shown that the variation in casting quality caused by uncontrollable process variables can be minimized. The concept of robust design for the process and the product introduced by G. Taguchi $[5,6]$ seeks to make both the process and the product insensitive to disturbing factors that occasionally or systematically affect the variability of the process that may lead to imperfections in the products [7].

In the present study, aluminium alloy test castings of same shape and size produced by sand mould casting process at selected sand grain size (or GFN - Grain Fineness Number), clay content, moisture content and number of ramming are studied and presented. The produced castings were examined for mechanical properties. The aim is to determine the optimum levels at which these parameters produce good quality castings. Many casting defects occur because the optimum conditions were not used during the casting process. By this 
study it is concluded that the data obtained can be applied to set the parameters at optimum level for improving mechanical properties so that the defects are minimized for aluminium-alloy sand castings.

The experiments are conducted by keeping 4 parameters at 3 levels; the number of experiments required was $3^{4}=81$ under Full Factorial Method. Using Taguchi's Orthogonal Array Technique number of experiments is reduced to ' 9 ' by choosing $\mathrm{L}_{9}$ orthogonal array. These 9 experiments were conducted in order to optimize the process parameters to achieve castings with less defects and improved mechanical properties.

\section{DESIGN OF EXPERIMENT}

The objective of present study is to identify most influencing process parameters of aluminum alloy sand casting process and optimize them to improved mechanical properties i.e.; tensile strength. Taguchi Design of Experiment is applied to assess the influence of parameters on tensile strength of casting.

Table 1: Control factors and their levels

\begin{tabular}{|c|c|c|c|c|}
\hline \multirow{2}{*}{ FACTOR } & \multirow{2}{*}{ CODE } & \multicolumn{3}{|c|}{ LEVEL } \\
\cline { 3 - 5 } & & I & $\mathbf{2}$ & $\mathbf{3}$ \\
\hline $\begin{array}{c}\text { Grain Fineness } \\
\text { Number }\end{array}$ & $\mathrm{A}$ & 40 & 55 & 70 \\
\hline Clay Content & $\mathrm{B}$ & $6 \%$ & $9 \%$ & $12 \%$ \\
\hline $\begin{array}{c}\text { Moisture } \\
\text { Content }\end{array}$ & $\mathrm{C}$ & $7 \%$ & $10 \%$ & $13 \%$ \\
\hline $\begin{array}{c}\text { Number of } \\
\text { Ramming }\end{array}$ & $\mathrm{D}$ & 2 & 3 & 4 \\
\hline
\end{tabular}

Table 2: $L 9\left(3^{4}\right)$ Standard Orthogonal Array

Table 3: Experimental design

\begin{tabular}{|c|c|c|c|c|}
\hline Expt. No. & A & B & C & D \\
\hline $\mathbf{1}$ & 1 & 1 & 1 & 1 \\
\hline $\mathbf{2}$ & 1 & 2 & 2 & 2 \\
\hline $\mathbf{3}$ & 1 & 3 & 3 & 3 \\
\hline $\mathbf{4}$ & 2 & 1 & 2 & 3 \\
\hline $\mathbf{5}$ & 2 & 2 & 3 & 1 \\
\hline $\mathbf{6}$ & 2 & 3 & 1 & 2 \\
\hline $\mathbf{7}$ & 3 & 1 & 3 & 2 \\
\hline $\mathbf{8}$ & 3 & 2 & 1 & 3 \\
\hline $\mathbf{9}$ & 3 & 3 & 2 & 1 \\
\hline
\end{tabular}

\begin{tabular}{|c|c|c|c|c|}
\hline \multirow{2}{*}{$\begin{array}{c}\text { Expt. } \\
\text { No. }\end{array}$} & GFN & Clay content & $\begin{array}{c}\text { Moisture } \\
\text { content }\end{array}$ & $\begin{array}{c}\text { No. of } \\
\text { Ramming }\end{array}$ \\
\hline $\mathbf{1}$ & $\mathbf{A}$ & $\mathbf{B}$ & $\mathbf{C}$ & $\mathbf{D}$ \\
\hline $\mathbf{2}$ & 40 & $6 \%$ & $7 \%$ & 2 \\
\hline $\mathbf{3}$ & 40 & $9 \%$ & $10 \%$ & 3 \\
\hline $\mathbf{4}$ & 55 & $12 \%$ & $13 \%$ & 4 \\
\hline $\mathbf{5}$ & 55 & $6 \%$ & $10 \%$ & 4 \\
\hline $\mathbf{6}$ & 55 & $12 \%$ & $7 \%$ & 2 \\
\hline $\mathbf{7}$ & 70 & $6 \%$ & $13 \%$ & 3 \\
\hline $\mathbf{8}$ & 70 & $9 \%$ & $7 \%$ & 4 \\
\hline $\mathbf{9}$ & 70 & $12 \%$ & $10 \%$ & 2 \\
\hline
\end{tabular}

\section{EXPERIMENTAL WORK}

\subsection{Preparation of Pattern}

A solid square section wooden pattern with side $30 \mathrm{~mm} \times 30 \mathrm{~mm}$ and length $160 \mathrm{~mm}$ is prepared, as shown in Fig. 1, to make a mould in which molten metal is poured to produce castings which is used to prepare tensile test specimen.

\subsection{Preparation of Sand Moulds}

A total of Nine Dry sand moulds are prepared, as shown in Fig. 2, using silica sand as base sand, bentonite powder as clay or binder, and water as moisture. Moulds are prepared by varying grain fineness of silica sand (40, 55 and 70$)$, clay content $(6 \%, 9 \%$ and $12 \%$ by weight), moisture content $(7 \%, 10 \%$ and $13 \%$ by weight) and number of ramming ( 2,3 and 4$)$; as per the experimental design. 


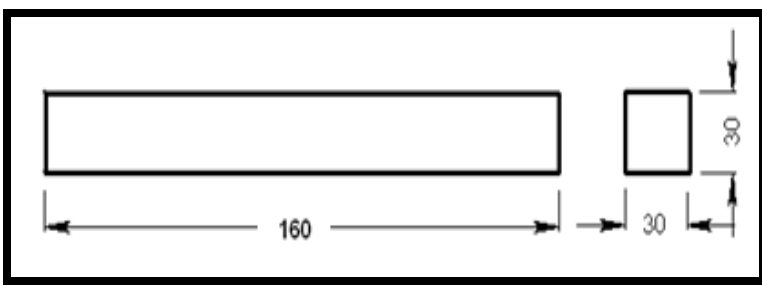

Figure 1: Pattern dimensions

3.3 Preparation of Test Castings

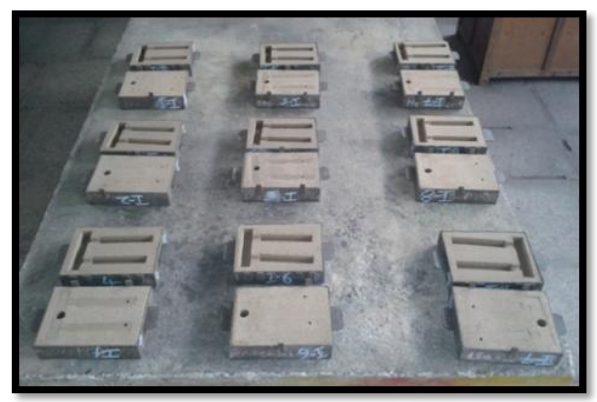

Figure 2: Dry Sand Moulds ready for pouring

3.3.1 Material composition

Table 4: Chemical Composition of Aluminium alloy A356

\begin{tabular}{|c|c|c|c|c|c|c|c|c|c|c|c|}
\hline Elements & $\mathbf{S i}$ & $\mathbf{C u}$ & $\mathbf{M g}$ & $\mathbf{F e}$ & $\mathbf{Z n}$ & $\mathbf{M n}$ & $\mathbf{C r}$ & $\mathbf{T i}$ & $\mathbf{P b}$ & $\mathbf{A l}$ & $\mathbf{N i}$ \\
\hline $\boldsymbol{\%}$ & 6.29 & 0.05 & 0.34 & 0.70 & 0.05 & 0.33 & 0.01 & 0.03 & 0.02 & 92.1 & 0.01 \\
\hline
\end{tabular}

\subsubsection{Melting Furnace}

The melting was done in lift out crucible type coke fired pit furnace.

\subsubsection{Degassing}

Absorption of hydrogen gas in the molten aluminium is shown in the equation-1. The hydrogen gas thus liberated in the reaction occupies the interstitial spaces of metal leading to porosity if not removed.

$$
2 \mathrm{Al}+3 \mathrm{H}_{2} \mathrm{O} \rightarrow \mathrm{Al}_{2} \mathrm{O}_{3}+6 \mathrm{H} \uparrow-----(1)
$$

Hexa-chloro-ethane $\left(\mathrm{C}_{2} \mathrm{Cl}_{6}\right)$ tablets are added to the molten metal for the purpose of degassing, as shown in Fig. 3. Equation-2 shows the chemical reaction that liberates stable chlorine gas, thus flushing hydrogen gas by creating partial pressure in molten metal.

$$
\mathrm{C}_{2} \mathrm{Cl}_{6} \rightarrow 2 \mathrm{C}+3 \mathrm{Cl}_{2} \uparrow
$$

3.3.4 Fluxing

Coveral-36 is used as a flux to protect the molten charge from getting oxidized.

\subsubsection{Pouring and Fettling}

Test castings are prepared by pouring the molten metal into the moulds, shown in Fig.4. After solidification the moulds are broken to get the castings out, as in Fig.5.

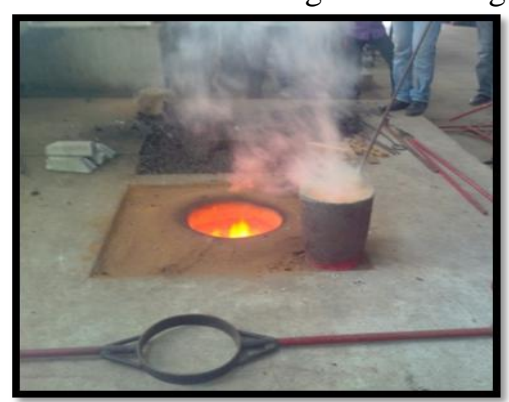

Figure 3: Degassing process

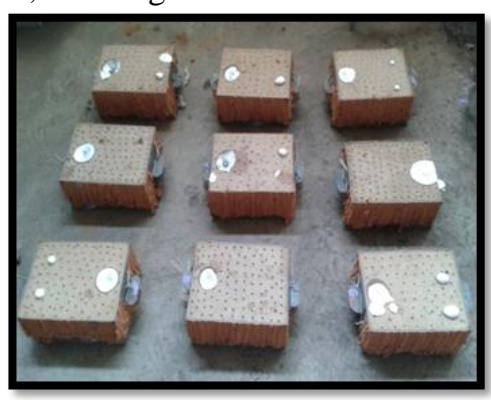

Figure 4: Sand molds after pouring

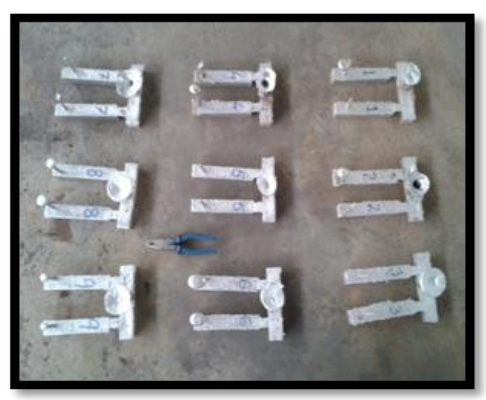

Figure 5: Test castings after fettling

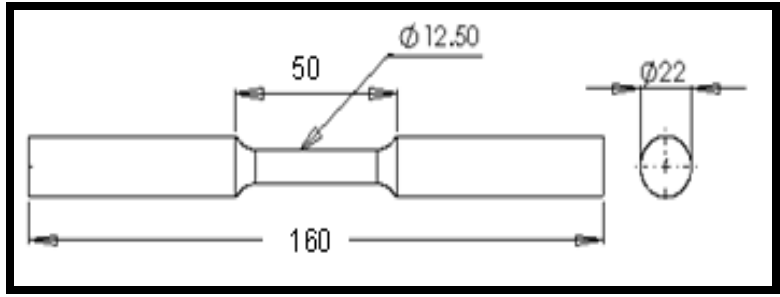

Figure 6: Tensile test specimen dimensions

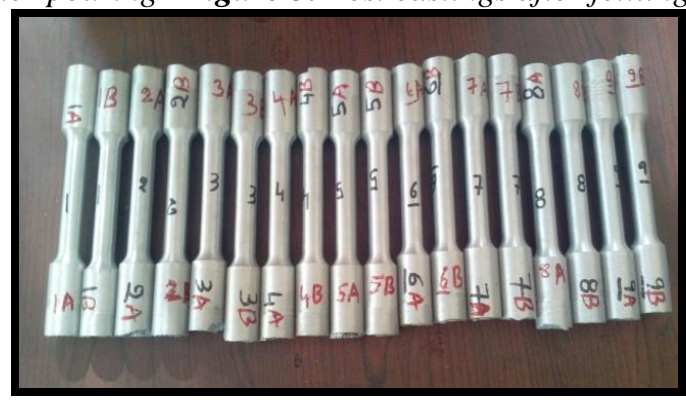

Figure 7: Tensile test specimen samples 
Finally machining operations are performed on CNC machine to prepare standard test specimens for measuring tensile strength, as shown in Fig.7. Universal Testing Machine: UTE - 40 is used for tensile strength measurement.

\section{RESULTS AND DISCUSSION}

The results obtained as per the designed experiment are listed in Table 5. The values of tensile strength are obtained for each sample.

Table 5: Experiment Results

\begin{tabular}{|c|c|c|c|c|c|}
\hline \multirow{2}{*}{$\begin{array}{c}\text { Expt. } \\
\text { No. }\end{array}$} & GFN & $\begin{array}{c}\text { Clay } \\
\text { Content }\end{array}$ & $\begin{array}{c}\text { Moisture } \\
\text { content }\end{array}$ & $\begin{array}{c}\text { No. of } \\
\text { Ramming }\end{array}$ & Response \\
\cline { 2 - 6 } & $\mathbf{A}$ & $\mathbf{B}$ & $\mathbf{C}$ & $\mathbf{D}$ & $\begin{array}{c}\text { Tensile } \\
\text { Strength } \\
\text { (MPa) }\end{array}$ \\
\hline $\mathbf{1}$ & 40 & $6 \%$ & $7 \%$ & 2 & 104.5 \\
\hline $\mathbf{2}$ & 40 & $9 \%$ & $10 \%$ & 3 & 106.8 \\
\hline $\mathbf{3}$ & 40 & $12 \%$ & $13 \%$ & 4 & 125.7 \\
\hline $\mathbf{4}$ & 55 & $6 \%$ & $10 \%$ & 4 & 102.9 \\
\hline $\mathbf{5}$ & 55 & $9 \%$ & $13 \%$ & 2 & 119.2 \\
\hline $\mathbf{6}$ & 55 & $12 \%$ & $7 \%$ & 3 & 117.7 \\
\hline $\mathbf{7}$ & 70 & $6 \%$ & $13 \%$ & 3 & 111.1 \\
\hline $\mathbf{8}$ & 70 & $9 \%$ & $7 \%$ & 4 & 108.9 \\
\hline $\mathbf{9}$ & 70 & $12 \%$ & $10 \%$ & 2 & 114.8 \\
\hline & & & & Total & 1011.6 \\
\hline & & & & Mean & 112.4 \\
\hline
\end{tabular}

\subsection{S/N ratio calculations}

For larger the better $\mathrm{S} / \mathrm{N}$ ratio is

$$
S / N=-10 \log _{10}\left(\frac{1}{n} \sum_{i=1}^{n} \frac{1}{y_{i}^{2}}\right)
$$

4.1.1. S/N ratio for Tensile strength

$\mathrm{S} / \mathrm{N}$ ratio for experiment 1 for Tensile strength is

$$
S / N_{1}=-10 \log _{10}\left(\frac{1}{1}\left(\frac{1}{104.5^{2}}\right)\right)=40.38
$$

Similarly $\mathrm{S} / \mathrm{N}$ ratio values for tensile strength for all the nine experiments are calculated and tabled as shown in Table 6.

The average $\mathrm{S} / \mathrm{N}$ value is calculated for each factor $\mathrm{A}$ at level 1.

$\mathrm{S} / \mathrm{N}_{\mathrm{A}, 1}=$ Average $\mathrm{S} / \mathrm{N}$ ratio for factor $\mathrm{A}$ at level 1

$\mathrm{S} / \mathrm{N}_{\mathrm{A}, 1}=(40.38+40.57+41.98) / 3=40.97$

Similarly the average $\mathrm{S} / \mathrm{N}$ value is calculated for each factor and each level for tensile strength, and tabulated as shown in the Table 7. 
Table 6: S/N Ratio

\begin{tabular}{|c|c|c|c|c|c|}
\hline $\begin{array}{c}\text { Expt. } \\
\text { No. }\end{array}$ & A & B & C & D & S/N Ratio \\
\hline $\mathbf{1}$ & 1 & 1 & 1 & 1 & Tensile Strength \\
\hline $\mathbf{2}$ & 1 & 2 & 2 & 2 & 40.38 \\
\hline $\mathbf{3}$ & 1 & 3 & 3 & 3 & 40.57 \\
\hline $\mathbf{4}$ & 2 & 1 & 2 & 3 & 41.98 \\
\hline $\mathbf{5}$ & 2 & 2 & 3 & 1 & 40.24 \\
\hline $\mathbf{6}$ & 2 & 3 & 1 & 2 & 41.52 \\
\hline $\mathbf{7}$ & 3 & 1 & 3 & 2 & 41.41 \\
\hline $\mathbf{8}$ & 3 & 2 & 1 & 3 & 40.91 \\
\hline $\mathbf{9}$ & 3 & 3 & 2 & 1 & 40.74 \\
\hline
\end{tabular}

Table 7: S/N Ratio Response for Tensile Strength

\begin{tabular}{|c|c|c|c|c|}
\hline LEVEL & A & B & C & D \\
\hline $\mathbf{1}$ & 40.97 & 40.51 & 40.99 & 41.03 \\
\hline $\mathbf{2}$ & 41.05 & 40.94 & 40.64 & 40.96 \\
\hline 3 & 40.94 & 41.52 & 41.47 & 40.98 \\
\hline Max-Min & 0.11 & 1.01 & 0.83 & 0.07 \\
\hline Rank & 3 & 1 & 2 & 4 \\
\hline $\begin{array}{c}\text { Optimum } \\
\text { level }\end{array}$ & $\mathrm{A}_{2}$ & $\mathrm{~B}_{3}$ & $\mathrm{C}_{3}$ & $\mathrm{D}_{1}$ \\
\hline
\end{tabular}

\subsection{Response Curves}

From the $\mathrm{S} / \mathrm{N}$ ratio response tables the optimum levels for selected process parameters are $\mathrm{A}_{2}, \mathrm{~B}_{3}, \mathrm{C}_{3}$ and $\mathrm{D}_{1}$ that is GFN - 55; Clay Content - 12\%; Moisture Content - 13\% and No. of Ramming - 2 respectively. The response curves drawn are shown in the Fig. 8.

Where,

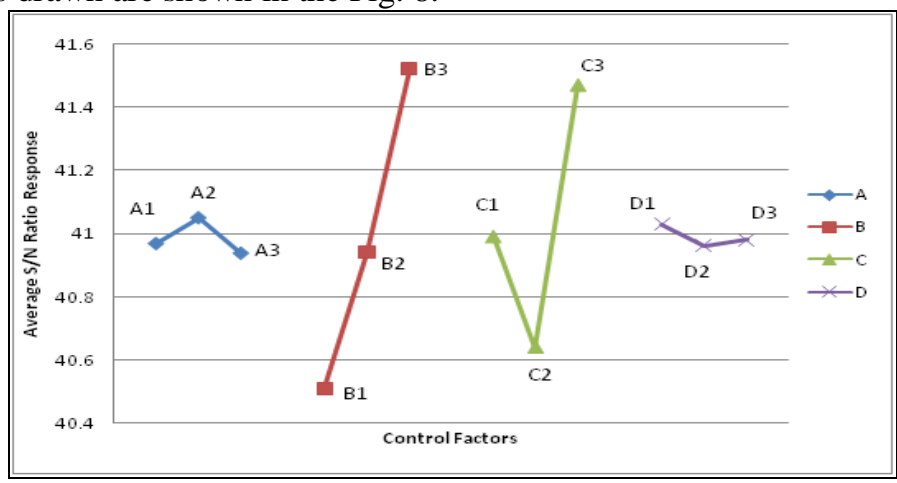

Figure 8: Response curve of Tensile strength

A - GFN, B - Clay Content, C - Moisture Content, and D - Number of Ramming.

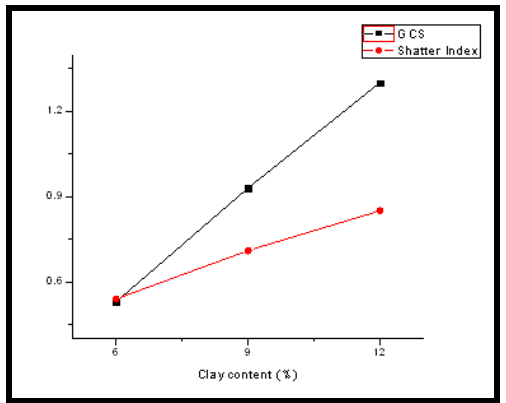

Figure 9:

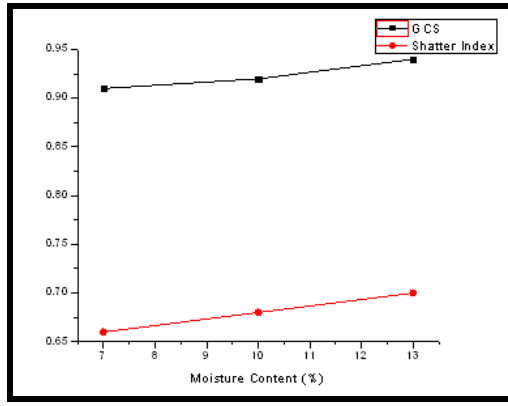

(b)

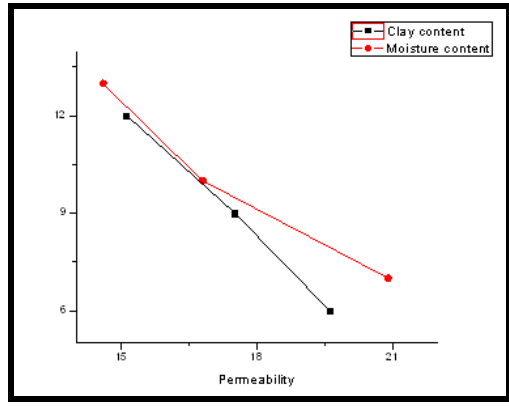

(c)

Fig. 9(a) shows the effect of clay content on green compressive strength (GCS) and shatter index, Fig. 9(b) shows the effect of moisture content on green compressive strength and shatter index and Fig. 9(c) shows the effect of permeability on clay content and moisture content.

\subsection{Discussion}

From the graphs it is clear that both the clay content and moisture content present in the sand are affecting the green compressive strength, shatter index and permeability properties of the sand mold. As the clay content increases GCS and shatter index increases. Similarly when moisture content is increased there is an increase in GCS and also shatter index. With increase in clay content and moisture content of the sand, the permeability property of the mould decreases. Hence it is essential to optimize the amount of clay and moisture present in the sand mold.

The increase in clay content will decrease the permeability, thereby increasing the porosity defects in the casting which reduces the mechanical properties. If the clay content decreases the green compression strength, shatter index and mold hardness decreases thereby decreasing the mould quality. 
If the moisture content is increased, the permeability decreases and thereby affecting the casting quality. Moreover the moisture content will produce much amount gases at the time of pouring molten metal, thus resulting in casting defects like porosity, blow holes, pin holes, etc. Therefore optimum values of clay content and moisture content are to be selected.

\subsection{Confirmation Test:}

Confirmation test for tensile strength is conducted based on the optimum level of process parameters i.e.; GFN - 55, Clay content - $12 \%$, Moisture content - $13 \%$ and Number of Ramming - 2 . The confirmation result for tensile strength is found to be $130 \mathrm{MPa}$. Hence the Tensile strength of aluminum alloy castings produced by sand casting process is increased from $103 \mathrm{MPa}$ to $130 \mathrm{MPa}$.

\section{CONCLUSIONS}

The experiments conducted have shown that the process parameters selected have significant influence on mechanical properties of aluminium alloy sand casting.

- Clay Content and Moisture Content are the major control factors among the selected factors for the improvement of mechanical properties.

- Both clay content and moisture content are affecting green compressive strength, Shatter Index, and Permeability of the sand mold.

- The optimum levels for process parameters are: GFN - 55, Clay content - 12\%, Moisture content $13 \%$, Number of ramming - 2 times.

- The confirmation result for tensile strength for optimum level of process parameters is found to be 130 MPa. Tensile strength of aluminum alloy castings produced by sand casting process is increased from $103 \mathrm{MPa}$ to $130 \mathrm{MPa}$.

\section{REFERENCES}

[1] Zillur Rahman and Faisal Talib, A Study of Optimization of Process by Using Taguchi's Parameter Design Approach, The Icfai University Journal of Operations Management, Vol. VII, No. 3, 2008

[2] Mekonnen Liben Nekere, Ajit Pal Singh, Optimization of aluminium blanks sand casting for process by using Taguchi Robust Design Method, International Journal for Quality research Vol.6, No.1, 2012, 81-97.

[3] Datta, G.L., Sand and mould related casting defects, Indian Foundry Journal, 44(9), 1998, 148-154

[4] Johnston R.E., Design of experiments: Taguchi in the foundry, AFS Trans 82, 1989, 415-418.

[5] Taguchi G., Introduction to quality engineering: design quality into products and process, (Asian Productivity Organization, Tokio, 1986).

[6] Phadke M.S., Quality Engineering Using Robust Design (Prentice Hall, Englewood Cliffs, NJ, 1989).

[7] Rasik A Upadhye and Dr. Ishwar P Keswani, Optimization of Sand Casting Process Parameter Using Taguchi Method in Foundry, International Journal of Engineering Research \& Technology (IJERT) Vol. 1 Issue 7, September - 2012.

[8] Jhon O. OJI, Buliamin Kareem and Idusuy, Effect of Mould and Pouring Temperatures on Ultimate Tensile strength of Aluminium Alloy Sand Castings - An ANOVA Approach, Leonardo Electronic Journal of Practices and Technologies, Issue 19, JulyDecember 2011, p. 97-108. 